\title{
A szív pozitív inotróp támogatása a miozin-aktivátor hatású omecamtiv mecarbil segítségével
}

\author{
Nagy László, Gödény Ildikó², Nánási Péter³, Leskó Ádám4, Balogh László, \\ Bánhegyi Viktor', Bódi Beáta', Csípő Tamás', Csongrádi Alexandra', \\ Fülöp Gábor Áron', Kovács Árpád', Lódi Mária', Papp Zoltán'
}

\author{
${ }^{1}$ Debreceni Egyetem, Általános Orvostudományi Kar, Klinikai Fiziológiai Tanszék, Debrecen \\ ${ }^{2}$ Kenézy Gyula Kórház és Rendelőintézet, Központi Aneszteziológiai és Intenzív Terápiás Osztály, Debrecen \\ ${ }^{3}$ Debreceni Egyetem, Általános Orvostudományi Kar, Biofizikai és Sejtbiológiai Intézet, Debrecen \\ ${ }^{4}$ Debreceni Egyetem, Általános Orvostudományi Kar, Orvosi Képalkotó Klinika, Debrecen
}

Levelezési cím: Prof. dr. Papp Zoltán, 4032 Debrecen, Móricz Zs. krt. 22., E-mail: pappz@med.unideb.hu

Jelenleg a kereskedelmi forgalomban még nem érhetőek el a szív mechanikai funkciójának támogatására azok az újnak tekintett gyógyszerek, amelyekre, mint kardiális miozin-aktivátorok hivatkoznak. Az omecamtiv mecarbil, mint a csoport egyetlen ismert képviselője előzetes preklinikai vizsgálatokban hatékonynak tủnt. Továbbá bíztató eredmények láttak napvilágot a már lezárt I. és II. fázis klinikai vizsgálatokban is. A vegyület pontos hatásmechanizmusával és biztonságosságával kapcsolatban azonban még nem rendelkezünk kiterjedt ismeretekkel. Jelen áttekintés célja az, hogy a rendelkezésre álló laboratóriumi és klinikai adatok tükrében értékelje az omecamtiv mecarbil várható klinikai használhatóságát.

Kulcsszavak: miozin-aktivátorok, omecamtiv-mecarbil, pozitív inotrópia, szívelégtelenség, Ca+érzékenyítő pozitív inotróp vegyületek

Inotropic therapy with the myosin activator omecamtiv mecarbil

The novel cardiotonic drugs, called cardiac myosin activators have not been commercialized for clinical administrations yet. Omecamtiv mecarbil, the only known representative of the above class of drugs, appeared to be effective in preclinical investigations. Moreover, promising results have been also reported for phase I and phase II clinical trials as well. Nevertheless, our understanding on the exact mechanism of action and safety of omecamtiv mecarbil is still limited. The aim of the present overview is to summarize the currently available preclinical and clinical data on omecamtiv mecarbil, and thereby to estimate its potential clinical benefit.

Keywords: myosin activators, omecamtiv mecarbil, positive inotropy, heart failure, $\mathrm{Ca}^{2+}$ sensitiser positive inotrope agents

\section{Bevezetés}

Melyek az ideális pozitív inotróp vegyülettel szemben támasztott elvárások?

Napjainkra már többszörösen igazolt tény, hogy a szív pumpafunkcióját támogató konvencionális pozitív inotróp hatású gyógyszerek alkalmazása - a kedvező hemodinamikai hatások dacára - nem problémamentes, hiszen alkalmazásuk fokozott mortalitással járhat (1-3).
Mivel minden szempontból meggyőző pozitív inotróp hatású szer továbbra sem áll a rendelkezésünkre, az inotrópia a farmakológiai kutatások számára ma is célterületként szerepel. A kívánatos az lenne, ha olyan kardiotonikus szereket sikerülne kifejleszteni, amelyek úgy javítanák a myocardium teljesítményét, hogy ezzel párhuzamosan nem fokozódna a szív oxigénfogyasztása. Az ideális pozitív inotróp szerekkel szemben továb- 
bi elvárás, hogy azok ne eredményezzenek sejtkárosodást, hatásuk szívizom-specifikus legyen, és aritmogén potenciállal se rendelkezzenek (4).

A miozin-aktivátorok fejlesztésekor a fenti szempontoknak megfelelő új vegyületcsoportot kívántak létrehozni. Az omecamtiv mecarbil (OM) a miozin-aktivátorokként definiált új gyógyszercsoport szívgyógyászati alkalmazásra szánt jelenleg ismert egyetlen gyógyszerjelölt képviselője.

\section{Milyen celluláris mechanizmusok miatt romlik a szívizomsejtek funkciója?}

A szívizomsejtek összehúzódásai és elernyedései, és ezért a szív pumpafunkciója is, alapvetően az intracelluláris $\mathrm{Ca}^{2+}$-koncentráció $\left[\mathrm{Ca}^{2+}\right]$ tranziens változásainak (röviden $\mathrm{Ca}^{2+}$-tranziens) sajátosságain (amplitúdó, kinetika, diasztolés $\left[\mathrm{Ca}^{2+}\right]$ ), és az arra reagáló összehúzódásra képes (konktraktilis) fehérjerendszer kölcsönhatásán múlik. Különböző kóreredetű szív- és érrendszeri megbetegedések következtében a szív pumpafunkciója gyakorta romlik. A krónikus szívelégtelenség kialakulása során neurohumorális mechanizmusok (pl. fokozódó renin-angiotenzin-aldoszteron-rendszer aktivitás és szimpatikus tónus, a natriuretikus faktorok szintjének emelkedése) érvényesülnek, amelyek rövidtávon támogathatják a keringést, azonban hosszabb távon tovább rontják a szív funkcióját. A nyomás- és volumen-túlterhelés talaján előbb-utóbb kialakul a myocardium kompenzatórikus hipertrófiája is. A kamrák tökéletlen ürülése később a szívüregek dilatációjához és ezzel a szívizomrostok megnyúlásához vezet, ami a kontraktilis diszfunkciót elmélyíti. A neurohumorális rendszer túlmúködése végül a szívizomsejtek nekrózisát, apoptózisát és az extracelluláris mátrix átépülését (fibrózis), összességében a szívizomzat strukturális és funkcionális átépülését („remodellingjét”) eredményezi (5). Mindezen folyamatok következtében szívelégtelenség alakul ki. A szívelégtelenségben érvényre jutó sokrétű sejtfolyamat között két kulcsfontosságú összetevő emelendő ki, az egyik a $\mathrm{Ca}^{2+}$-háztartás sejtszintű zavara, a másik a kontraktilis rendszer diszfunkciója (abnormális aktin-miozin interakció). Ezek vázlatos ismertetése a szívelégtelenség kezelésében használt konvencionális és újabb típusú inotróp szerek hatásmechanizmusai szempontjából egyaránt jelentőséggel bír $(6,7)$.

A szívizomsejtek $\mathrm{Ca}^{2+}$-homeosztázisának zavarát az elektromechanikai kapcsolat szabályozásában részt vevő regulátor fehérjék: pumpamechanizmusok, ioncsatornák, ioncserélők működésének károsodása idézi elő (8). Diszfunkciójuk eredményeképpen szisztolés szívelégtelenségben (HFrEF) szenvedő betegek szívizomsejtjeiben torzul az intracelluláris $\mathrm{Ca}^{2+}$-tranziens: annak amplitúdója csökken és időtartama jelentős mértékben megnyúlik, valamint emelkedik a diasztolés $\left[\mathrm{Ca}^{2+}\right]$ is (9). A szívizomsejtek kóros $\mathrm{Ca}^{2+}$-anyagcseréjének hátterében részben a szívizomsejteken belüli $\mathrm{Ca}^{2+}$-raktár, szarkoplazmatikus retikulum (SR) kóros müködése áll. $\mathrm{A} \mathrm{Ca}^{2+} \mathrm{SR}$-be történő felvétele lassú, a $\mathrm{Ca}^{2+}$-raktározás mértéke kórosan kicsiny (10), amelyek fő oka az SR felszínén elhelyezkedő SR $\mathrm{Ca}^{2+}$-ATPáz (SERCA) pumpa mennyiségének és aktivitásának hanyatlása $(11,12)$. A SERCA aktivitását szabályozó foszfolambán mennyiségének csökkenését, a SR-ből történő $\mathrm{Ca}^{2+}$-kiáramlást szabályozó rianodin receptorok és a szarkolemmális L-típusú $\mathrm{Ca}^{2+}$-csatornák kóros működése egészíti ki (13). A nyugalmi $\left[\mathrm{Ca}^{2+}\right]$ emelkedése kompenzáló $\mathrm{Ca}^{2+}$-eltávolító mechanizmusokat aktivál: a $\mathrm{Na}^{+} / \mathrm{Ca}^{2+}$-cserélő mennyiségének és aktivitásának növekedése magas intracelluláris $\mathrm{Na}^{+}$-koncentrációt hoz létre, amely az akciós potenciál alakját és időtartamát is módosíthatja (14). A kontraktilis rendszer kóros múködéséhez a kontraktilis filamentumokat alkotó strukturális és regulátor fehérjék expressziós szintjében bekövetkező változások, ezek poszttranszlációs módosulásai (pl. oxidatív károsodás, foszforilációs eltérések) járulnak hozzá $(15,16)$.

\section{A szarkomer felépítése és a kontrakció mechanizmusa}

A szívizomzat pumpafunkcióját javító gyógyszerek végeredményben a kardiális szarkomerek működését módosítják, ezért hatásmechanizmusuk ismertetéséhez elengedhetetlen a szarkomer felépítésének és a kontrakció mechanizmusának rövid áttekintése is. A myocardium alapvető szerkezeti egységét a kontrakciós erő generálására képes szarkomerek alkotják, amelyek szisztolés megrövidülése az ún. vastag (dominánsan miozin) és vékony (dominánsan aktin) filamentumok közötti kölcsönhatásnak köszönhető. A szarkomerek a váz- és szívizomzatban hasonló szerkezetűek, és mindkét izomféleségben a fénymikroszkóposan is látható harántcsíkoltságért felelősek. Az izom-összehúzódás élettani alapja, hogy a miozin molekulák ún. „feji” régiói az aktin molekulákkal ciklikus interakcióra lépnek, amelynek eredményeként a vékony filamentumok elmozdulnak a vastag filamentumokhoz képest, és ezért a szarkomer megrövidül („csúszó-filamentum modell”) (1. ábra). A miozin-fejek evezőcsapás-szerü konformáció-változásának („power-stroke”) létrejöttéhez közvetlen energiaforrásként ATP-re, és a $\mathrm{Ca}^{2+}$ által aktivált vékony filamentumokra van szükség. Diasztolé során a citoplazmatikus $\left[\mathrm{Ca}^{2+}\right]$ alacsony, a kontrakciót szabályozó troponin fehérje komplex (cTnl, cTnT, cTnC) és a tropomiozin megakadályozza az aktin-miozin kölcsönhatást. Szisztolé során az intracelluláris [ $\left.\mathrm{Ca}^{2+}\right]$ növekedése a vékony filamentum szerkezetében olyan konformáció változásokat idéz elő, ami lehetővé teszi az aktin-miozin ciklus kialakulását. Az összefoglalásunkban szereplő téma szempontjából ezen a ponton két fő interakciót kell kiemelnünk (1), a cTnC Ca ${ }^{2+}$ kötése megszünteti a cTnl-tropomiozin komplex aktin-miozin kölcsönhatásra gyakorolt gátló hatását, így (2) a vékony filamentumok miozin kötőhelyei hozzáférhetővé válnak 
A

\section{Levosimendan}

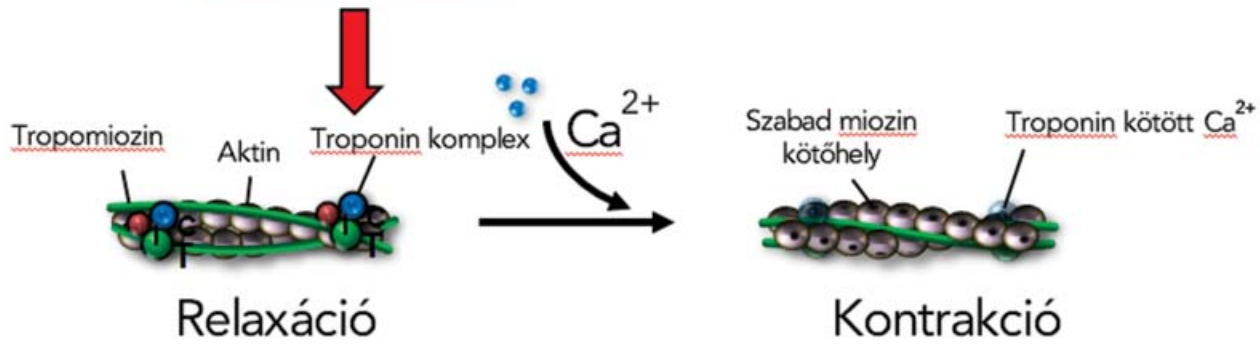

B

\section{Omecamtiv mecarbil}

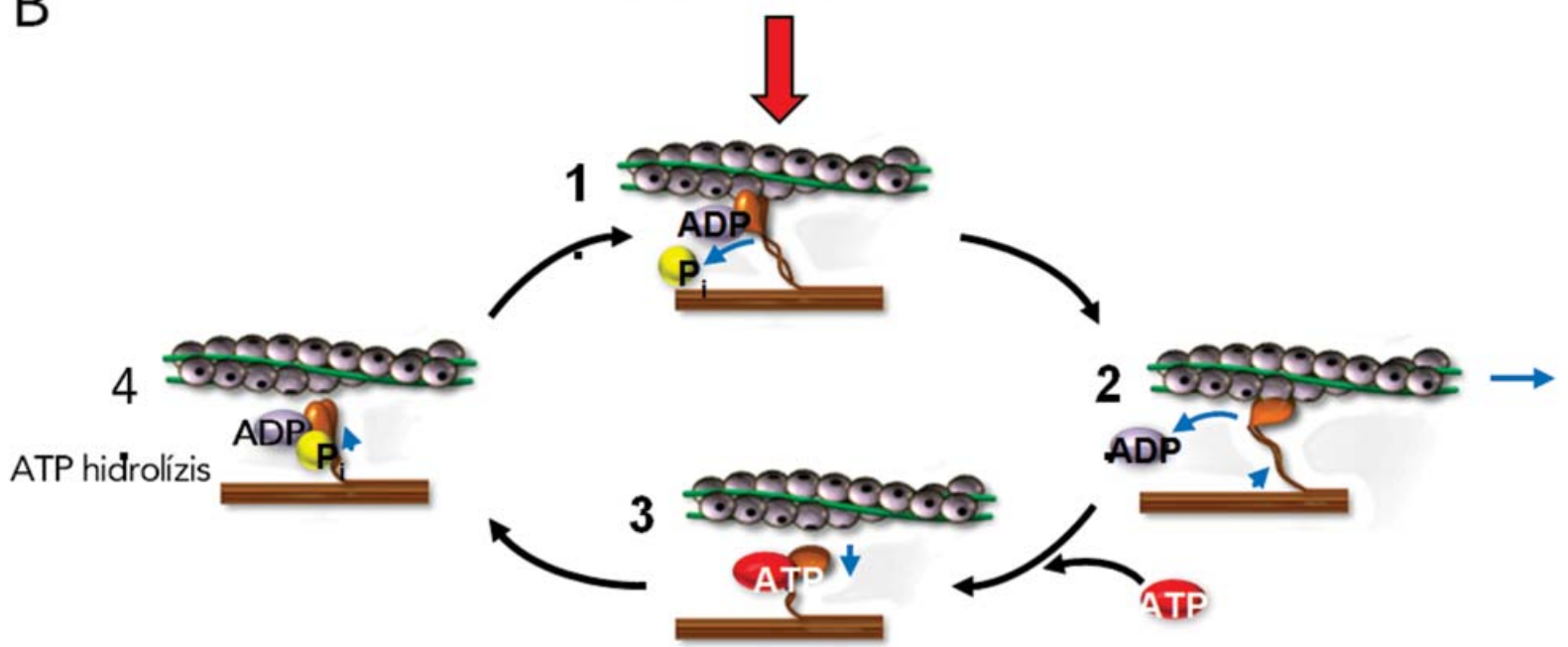

1. ÁBRA. A szívizomsejtek összehúzódásait biztosító kontraktilis fehérjerendszer vázlatos működése. A: A kontrakció kialakulásához a szívizomsejtekben felszabaduló kalcium-ionok $\left(\mathrm{Ca}^{2+}\right)$ a troponin-komplexhez kapcsolódva teszik elérhetővé az aktin monomerek miozin-kötő felszínét. B: Az aktin-miozin ciklus során az ATP-ben tárolt energia több lépésben konvertálódik a vékony és vastag filamentumok egymáshoz képest történő elmozdulásává, végeredményben mechanikai munkává. Az omecamtiv mecarbil az aktin-miozin ciklus $\mathrm{P}_{\mathrm{i}}$-disszociációs lépésének elősegítése révén növeli a munkát végző miozin-fejek számát. A Ca²+érzékenyítő levosimendan és a miozin-aktivátor omecamtiv-mecarbil támadásponjait vastag piros nyilak jelölik, a miozin-fejek konformációváltozásait vékony kék nyilak illusztrálják

a miozinfejek számára, megteremtve ezzel a lehetőséget az erőgeneráló aktin-miozin kereszthidak kialakítására (17-19).

\section{Az inotróp terápia helye az akut szívelégtelenség kezelésében}

Az akut szívelégtelenség kezelésének sikere a kiváltó okok felismerésén, azok gyors megszüntetésén (pl. akut koronária szindróma, hipertenzív krízis) és a hatékony szupportív kezelésen (diuretikumok, keringéstámogatás) múlik. Az Európai Kardiológiai Társaság (ESC) akut szívelégtelenséggel kapcsolatos irányelvei szerint az akut szívelégtelenség során választandó terápia a centrális és perifériás keringési zavar jeleinek és tüneteinek tükrében határozandó meg $(20,21)$. Intravénás diuretikumok és vazodilatátorok alkalmazása javasolt abban az esetben, amikor a dekompenzálódó beteg vérnyomása megtartott, vagy emelkedett (RR $>90 \mathrm{Hgmm}$ ), és heveny kisvérköri pangás uralja a klinikai képet. Azonban, ha a tünetek között perfúziós zavar jelei is észlelhetőek, különösen ha hipotenzió ( $R R<90 \mathrm{Hgmm}$ ) és kardiogén sokk lép fel, intravénás inotróp kezelést is érdemes választani a perctérfogat és a vérnyomás növelése érdekében $(20,22)$.

A keringéstámogatás céljából adott pozitív inotróp hatású gyógyszerek két fő mechanizmussal javíthatják a szív teljesítményét:

1. A $\mathrm{Ca}^{2+}$-mobilizáló konvencionális inotróp szerek növelik az intracelluláris $\left[\mathrm{Ca}^{2+}\right]$-t, amelyet vagy az adrenerg szignalizációs útvonalakra (pl. dopamin, dobutamin, foszfodiészteráz-gátlók), vagy a szívizomsejtek $\mathrm{Ca}^{2+}$-anyagcseréjére egyéb úton hatva (pl. digitálisz glikozidák, istaroxim) érnek el.

2. A szarkomert aktiváló szerek a szarkomerek müködését közvetlenül módosítják $(1,4)$. Utóbbi vegyületcsoportba tartozik a $\mathrm{Ca}^{2+}$-érzékenyítő levosimen- 
dan, és a miozin-aktivátor $O M$ is. Az utóbbi két évtized nagy klinikai tanulmányai kimutatták, hogy a szívizomzat csökkent pumpafunkciójának javítása céljából adott konvencionális pozitív inotróp hatású szerek nagy része ugyan kedvező hemodinamikai hatásokkal bír, de azok nem javították az akut szívelégtelenség prognózisát, sőt hosszabb távon a mortalitási és morbiditási adatokat még ronttották is (1-3). Ennek hátterében vélhetően a megnövekedett intracelluláris $\left[\mathrm{Ca}^{2+}\right]$ áll, amely fokozza a szívizomzat oxigénfogyasztását, aritmogén, növeli a szívfrekvenciát, és másodlagos jelátviteli útvonalakat aktiválva a szívizomsejtek apoptózisát és nekrózisát eredményezi.

\section{Szarkomert aktiváló szerek a szívelégtelenség kezelésében}

Szarkomert aktiváló szerek használatával elviekben elkerülhetjük a tradicionális inotrópok kedvezőtlen mellékhatásait, hiszen az aktin-miozin ciklus közvetlen módosítása mellett nem várható az intracelluláris $\left[\mathrm{Ca}^{2+}\right]$ növekedése. A szarkomert célzó szerek hatásmechanizmusa elsősorban (1) a miofilamentumok $\mathrm{Ca}^{2+}$-érzékenyítésén és/vagy (2) az ún. miozin-aktiváción alapulhat (1. ábra) $(4,22)$. A szívizomsejtek $\mathrm{Ca}^{2+}$-érzékenysége az egységnyi kontraktilis erő (pl. az izometriás körülmények között rögzített félmaximális erő) kifejtéséhez szükséges $\left[\mathrm{Ca}^{2+}\right]$-val $\left(\mathrm{pCa}_{50}\right)$ jellemezhető. $\mathrm{A} \mathrm{Ca}^{2+}$-érzékenység növelésére a szívizomsejtek adott intracelluláris $\left[\mathrm{Ca}^{2+}\right]$ mellett erősebb kontrakciós választ produkálnak. Elvi megfontolásokból következik, és kísérletesen is igazolt tény, hogy a $\mathrm{Ca}^{2+}-\mathrm{cTnC}$ interakció módosításán kívül (pl. levosimendan) a miozin közvetlen aktivációja szintén módosíthatja a szívizomsejtek $\mathrm{Ca}^{2+}$-érzékenységét (pl. az EMD 57033 és CGP-48506 jelü vegyületek segítségével) (1). Másképp fogalmazva, a miozin aktivációja is eredményezhet $\mathrm{Ca}^{2+}$-érzékenyítést, tehát a fenti két mechanizmus között éles különbséget tenni elvi alapon is nehéz. Érdemes hangsúlyozni, hogy a tisztán miofilamentális hatásokkal bíró szerek között korábbiakban még nem sikerült olyat kifejleszteni, amely maradéktalanul beváltotta volna a hozzájuk füzött reményeket. Így például az aktin-miozin interakcióra ható EMD 57033 ugyan hatékony pozitív inotróp hatásokkal rendelkezik, de iszkémiás szívizomzatban túlzottan fokozta a myocardium rigiditását (23).

\section{Miozin-aktiváció, mint új terápiás lehetőség a szívelégtelenség kezelésében}

A miozin-aktivátorok a kardiális miozin-molekulák enzimatikus müködésének modulációján keresztül fokozzák a szívizomsejtek kontraktilis erejét és ezzel a szív pumpafunkcióját. A gyógyszercsoport felfedezése az ezredforduló környékére tehető, amikor egy amerikai bi-<smiles>COC(=O)N1CCN(Cc2cccc(NC(=O)Nc3ccc(C)nc3)c2F)CC1</smiles>

2. ÁBRA. Az omecamtiv mecarbil (CK-1827452), (metil 4-[(2-fluoro-3-\{[N-(6-metilpiridin-3-il) karbamoil]amino\}fenil) metil] piperazin-1-karboxilát) szerkezete

otechnológiai cég daganatellenes gyógyszerek kifejlesztésével foglalkozott. A cél a sejtosztódás gátlása volt a mitotikus folyamatokban résztvevő kinezinek gátlásával. A kifejlesztett szerek között sok, meglepő módon a várt hatás ellenkezőjét produkálta, megnövelte a kinezinek aktivitását. Ez arra ösztönözte a kutatókat, hogy megvizsgálják, lehet-e más motoros fehérjék (pl. a miozin) aktiválását felhasználni különböző betegségek, így pl. szívelégtelenség terápiájára. Kivitelezhetőnek tűnt egy olyan szer fejlesztése, amely képes a kardiális miozin aktivációjával a szív pumpafunkcióját javítani. Hosszas vizsgálatok és több tucat lehetséges molekula tesztelése után jutottak el a legígéretesebb CK-1827452-nek elnevezett vegyülethez, későbbi nevén az omecamtiv mecarbilhoz (OM) (24) (2. ábra). Az OM a kardiális típusú miozin feji részén található motor domén $\mathrm{S1}$ régiójához kötődik. Ez a kölcsönhatás in vitro körülmények között a miozin-ATPáz aktivitásának fokozódását eredményezte. A molekuláris hatásmechanizmus szempontjából az OM feltalálói a miozin-fejekről történő anorganikus foszfát $\left(\mathrm{P}_{\mathrm{i}}\right)$ disszociáció gyorsítását tekintették a legfontosabb tényezőnek. Az aktin-miozin ciklus sebesség-meghatározó lépéseként is ismert $P_{\mathrm{i}}$-leválást közvetlenül követi az aktin-miozin ciklus erőgeneráló lépése (1. ábra). Ezért az OM-kiváltotta miozin-aktiváció - a javasolt elképzelés szerint - növelheti az adott pillanatban aktinnal reakcióba lépő és munkát végző miozin-fejek számát. A szívizomzat összehúzódása során ez a jelenség vezethet az izomerő növekedéséhez (25, 26). Mivel a kontrakciós erő az intracelluláris $\left[\mathrm{Ca}^{2+}\right]$ fokozódása nélkül jön létre, az OM hatásmechanizmusa $\mathrm{Ca}^{2+}$-érzékenyítésként is felfogható. Korábbi in vitro körülmények között végzett tanulmányok indirekt módon már utaltak az OM ezen hatására, hiszen a szer fokozta a miozin-ATPáz aktivitásának $\mathrm{Ca}^{2+}$-érzékenységét (25). $\mathrm{Az}$ OM miokardiális izomerőre kifejtett $\mathrm{Ca}^{2+}$-érzékenyítő hatását saját vizsgálatainkban később mi is egyértelmüen igazoltuk (27).

\section{Preklinikai vizsgálati eredmények omecamtiv mecarbillal}

Az OM hatékonyan fokozta patkányok bal kamrájából származó izolált, intakt szívizomsejtek kontraktilitását in 
vitro körülmények között, anélkül, hogy befolyásolta volna az intracelluláris $\mathrm{Ca}^{2+}$-homeosztázist. Ugyanakkor a szer a szívizomsejtek erejét úgy növelte, hogy e közben a kontrakciós válasz idejét is megnyújtotta. Az izomerő fokozódása anélkül alakult ki, hogy a kontrakciók kialakulásának üteme gyorsult volna (25). Mindezek alapján a szisztolés ejekciós idő növekedése a miozin-aktivációs hatás lényegi elemeként vált ismertté. Állatkísérletekben OM hatására a perctérfogat fokozódott, a szisztémás vaszkuláris rezisztencia és a szívfrekvencia (vélhetően a szimpatikus aktivitás mérséklődése miatt) csökkent $(25,28)$. Az OM in vivo hatékonyan javította infarktusos, valamint az aorta leszorításával szívelégtelenné tett kutyák bal kamrájának szisztolés funkcióit, ugyanakkor nem befolyásolta a diasztolés funkciót és nem növelte a szív oxigénfogyasztását sem (28). Egy másik, hasonló tanulmányban azonban az OM szignifikáns mértékben növelte az infarktuson átesett sertések bal kamrájának oxigénfogyasztását, amelynek hátterében a bazális ATPáz-aktivitás fokozódását vélték felismerni (29). Patkány eredetű izolált és permeabilizált szívizomsejteken végzett saját vizsgálatainkban az OM miokardiális kontraktilitásra gyakorolt hatásait és a vázizmokra kifejtett feltételezett hatásait tanulmányoztuk. Vizsgálatainkban az OM fokozta az izolált és permeabilizált szívizomsejteken mért kontraktilis erő $\mathrm{Ca}^{2+}$-érzékenységét, lassította az összehúzódásokhoz tartozó aktivációs - relaxációs ciklusok kinetikáját, növelte a $\mathrm{Ca}^{2+}$-független passzív erőgenerálás valószínűségét, valamint (nagy OM-kocentrációk mellett) igen alacsony $\left[\mathrm{Ca}^{2+}\right]-\mathrm{n}$ is kifejtette $\mathrm{Ca}^{2+}$-érzékenyítő hatásait. Mindezen hatások a szer potenciális diasztolés diszfunkciót okozó hatását vetítik előre, amely saját értékelésünk szerint nagyobb szívfrekvenciák mellett válhat elsősorban kritikussá. Az OM némileg kisebb hatékonysággal, de hasonló mechanikai és kinetikai hatásokkal rendelkezett rekeszizomból származó, lassú típusú vázizomrostokon is. Ezért a miozin-aktiváció elviekben terápiás lehetőséget nyújthat perifériás légzési elégtelenség és más vázizom-funkciót korlátozó kórállapot kezelésére is. Ennek a lehetőségnek az alapját az teremti meg, hogy a lassú típusú vázizomrostok szarkomereiben a szívizomsejtekkel teljesen identikus $\beta$-MHC miozin-izoforma található, amely az OM elsődleges molekuláris támadáspontja. Ezért az OM mechanikai funkcióra kifejtett hatását a szívizomsejteken kívül a lassú típusú izomrostokat tartalmazó vázizmokban is kifejti. Gyors típusú vázizomrostokban az OM csak minimális hatásokat váltott ki, amely az eltérő MHC-izoforma jelenlétével lehet összefüggésben (27). Összességében, saját vizsgálati eredményeink cáfolják azt, hogy az OM egy szívizom-specifikus miozin-aktivátor lenne, mivel jellegzetes hatásai némileg kisebb hatékonysággal, de lassú típusú vázizomrostokban is kialakultak. A vázizomrostok $\mathrm{Ca}^{2+}$-érzékenyítése révén a jövőben az OM-et (és annak potenciálisan kifejlesztendő származékait) a vázizomzat krónikus elgyengülésével járó kórképekben is kipróbálhatják majd, mint alternatív terápiás eszközt $(30,31)$. Jelenleg nem áll rendelkezésre olyan in vitro vagy in vivo tanulmány, amelyben az OM-hatásait vizsgálták volna légzési elégtelenségben. Érdekes, hogy az OM-hez hasonlóan a miozin nehéz láncán ható EMD 57033 is normalizálta sertésekből izolált és permeabilizált vázizomrostok csökkent $\mathrm{Ca}^{2+}$-érzékenységét (32).

\section{Klinikai vizsgálati eredmények omecamtiv mecarbillal}

A preklinikai tanulmányok zömmel kedvező eredményei után hamar megkezdődött az OM vizsgálata először egészséges önkénteseken, majd ezt követően szívelégtelenségben szenvedő betegekben is. A preklinikai vizsgálatokkal összhangban a szer intravénás adagolást követően fokozta mind az egészségesek, mind a szívelégtelen (NYHA III-IV.) betegek bal kamrájának szisztolés funkcióját, ugyanakkor nem befolyásolta a diasztolés paramétereket. A szer hemodinamikai hatásai az állatkísérletekben megismert mintázatot követték, jóllehet a változások mértéke némileg kisebb volt, és többnyire jól tolerálhatónak bizonyult. A dóziskereső tanulmány során alkalmazott legnagyobb koncentrációkban azonban egyes esetekben miokardiális iszkémia és nekroenzim-emelkedés lépett fel. A jelenség hátterében vélhetően a szisztolé idejének túlzott megnyújtása és ezzel összhangban a diasztolés intervallum megrövidülése állhatott $(33,34)$. Az OM kedvező kardiovaszkuláris hatásai megfigyelhetőek voltak orális adagolás után is (35). Az ATOMIC-HF-tanulmány alapján úgy tünt, hogy az OM egyes betegekben javította az elsődleges végpontnak tekintett nehézlégzést NYHA III-IV. stádiumú szívelégtelenség során, viszont hatása ebben a vonatkozásban a szignifikancia-küszöböt nem érte el (36). A COSMIC-HF-tanulmányban krónikus szívelégtelenségben (HFrEF) szenvedő betegek bal kamrájának szisztolés paramétereit vizsgálták. Az elérhető eredmények alapján a betegek jelentős javulást mutattak OM hatására (37). A preklinikai és klinikai adatok mellett egyelöre még nincs evidencia az OM hosszú távú hatásairól, illetve a szívelégtelenség mortalitására gyakorolt hatásról sem. A keményvégpontok vonatkozásában a jelenleg nagyszámú krónikus szívelégtelenség miatt hospitalizált beteg bevonásával megvalósuló III. fázisú klinikai tanulmány (GALACTIC-HF; NCT02929329) fog először adatokkal szolgálni.

\section{Az OM hatásmechanizmusa a jelenleg rendelkezésre álló adlatok tükrében}

Az eddigi adatok alapján bizonyítottnak tekinthető, hogy a miozin-aktivátorok a szívizomsejtek fő erőgeneráló alkotóeleméhez, a kardiális miozinhoz kapcsolódnak $(25,38)$. Ennek hatására fokozódik a $P_{i}$ disszociációja 
a miozin-fejekről, és elviekben ez javítja az aktin-miozin ciklus energetikai hatékonyságát. A fenti feltételezést részben in vivo tanulmányok is megerősítették (25, 28). Terápiás OM-koncentrációk mellett a szívizomsejtek intracelluláris $\mathrm{Ca}^{2+}$-anyagcseréje és ingerlékenységi folyamatai várhatóan nem fognak jelentősen módosulni $(39,40)$. Az újabb adatok és saját eredményeink alapján az OM hatásmechanizmusa azonban némileg újragondolásra szorul. Vizsgálati eredményeink egyértelmüen igazolták, hogy az OM Ca ${ }^{2+}$-érzékenyítés révén fokozza a lassú típusú vázizomrostok és a szívizom kontraktilitását. Ha a cTnC-Ca ${ }^{2+}$-interakciót tekintjük az összehúzódás szabályozásában a központi lépésnek, úgy az OM egy „downstream” típusú $\mathrm{Ca}^{2+}$-érzékenyítőnek felel meg. Ebből a megközelítésből a „miozin-aktivátor" csoport elkülönítése a korábbiakban már bevezetett $\mathrm{Ca}^{2+}$-érzékenyítő gyógyszercsoportoktól némileg önkényesnek tünik $(1,27)$. $\mathrm{A} \mathrm{Ca}^{2+}$-érzékenyítés jellemezhető azáltal, hogy milyen $\left[\mathrm{Ca}^{2+}\right]$ tartományban dominál. Más „downstream” típusú $\mathrm{Ca}^{2+}$-érzékenyítő szerekhez hasonlóan az OM akár diasztolés [Ca $\left.{ }^{2+}\right]-n$ is fokozhatja a miokardiális kontraktilitást. Hasonló hatást tapasztaltak az EMD 57033 vegyület alkalmazása során is, amely az OM kötőhelyéhez közel rögzül a miozin feji részének motor régiójában. OM jelenlétében diasztolés $\left[\mathrm{Ca}^{2+}\right]$ mellett is kialakítható volt a $\mathrm{Ca}^{2+}$-érzékenyítés, amelyet a [ $\left.\mathrm{Ca}^{2+}\right]$-kontraktilis erő összefüggés görbéjének felfelé tolódása reprezentált (3. ábra). A diasztolés $\left[\mathrm{Ca}^{2+}\right]-n$ létrejövő $\mathrm{Ca}^{2+}$-érzékenyítés viszont mindenképp felveti az OM okozta diasztolés diszfunkció veszélyét. Ez a probléma komolyan felmerült az OM-hez részben hasonló farmakológiai hatásokkal bíró

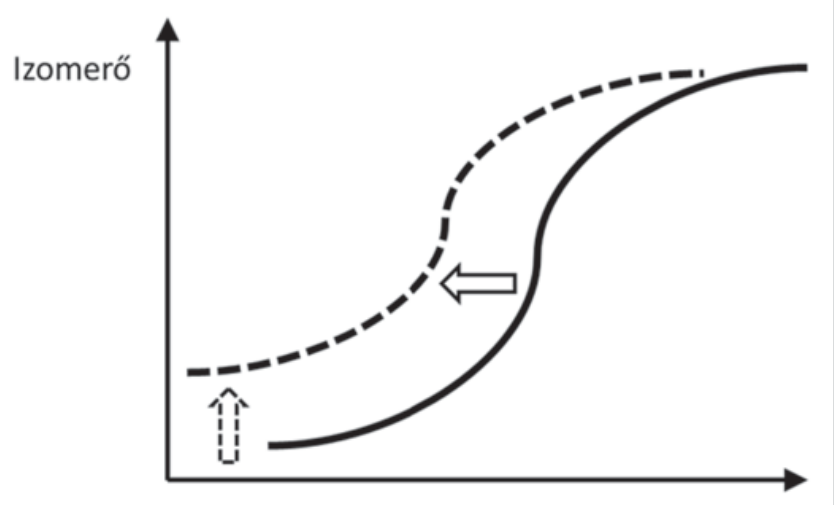

$\left[\mathrm{Ca}^{2+}\right]$

3. ÁBRA. Omecamtiv mecarbil hatására a szívizomsejtek és a lassú típusú vázizomrostok által generált erő $\mathrm{Ca}^{2+}$-érzékenysége fokozódik. A folyamatot a folytonos vonallal határolt nyíl illusztrálja, amely a folytonossal jelölt kontroll szigmoid lefutású $\mathrm{Ca}^{2+}$-érzékenységi görbe szaggatottal jelzett fokozott $\mathrm{Ca}^{2+}$-érzékenységi állapot felé történő átmenetével jellemezhető. Nagyobb OM koncentrációk jelenlétében a kontraktilis rendszer teljes relaxációja nem következik be (szaggatott vonallal határolt nyíl)
EMD 57033 esetében is, amely in vitro és in vivo állatmodellekben fokozta a myocardium rigiditását (41-43). OM-mel végzett kezelés kapcsán a diasztolés diszfunkció valószínúségét tovább fokozhatja a szívizomsejtek HFrEF-ben kialakuló kóros $\mathrm{Ca}^{2+}$-homeosztázis. Továbbá, szívelégtelenségben a kontraktilitás csökkenésére adott kompenzatorikus mechanizmusként eleve fokozódhat a miofilamentumok $\mathrm{Ca}^{2+}$-érzékenysége (44). $\mathrm{Az} \mathrm{OM}$-indukált diasztolés $\mathrm{Ca}^{2+}$-érzékenyítést tovább komplikálhatja a szívizomsejtek emelkedett diasztolés $\left[\mathrm{Ca}^{2+}\right]$-ja (23). Az in vitro adatokkal összhangban egy szívelégtelen patkányokon végzett tanulmányban az OM diasztolés diszfunkciót váltott ki, amelyet az izovolumetriás relaxáció időkonstansának (T) és a bal kamrai diasztolés nyomásváltozás sebesség-csökkenésének $\left(\mathrm{dP} / \mathrm{dt}_{\mathrm{min}}\right)$ kóros változása illusztrált (45). Annak ellenére, hogy a humán tanulmányok egyértelmüen még nem igazolták az OM diasztolés funkcióra gyakorolt hátrányos hatásait, a szer adagolása nagyfokú óvatosságot igényel. Az egészséges önkénteseken végzett humán tanulmányokban ugyanis az OM kismértékben növelte a diasztolés funkcióval korreláló izovolumetriás relaxációs időt (IVRT), valamint az E/e' hányadost is (33).

Az OM hatásmechanizmusának kulcsát a kezdeti tanulmányok elsősorban az ATPáz-aktivitás fokozódásában látták (25). Újabb tanulmányok viszont részben megkérdőjelezték ezt a hipotézist. Utóbbiak ugyanis nem tudtak könnyen értelmezhető magyarázatot adni arra a jelenségre, miszerint az OM csökkenti az aktin-miozin ciklus sebességét. Állandónak tekintett vékony filamentum aktivációs szintet feltételezve, az aktin-miozin ciklus lassulásából ugyanis nehézkesen vezethető le az ATPáz-aktivitás fokozódása. A legfrissebb adatok szerint az OM a fenti esetben inkább csökkentené a miozin ATPáz aktivitását, mintsem fokozná azt. Tehát egyáltalán nem zárható ki, hogy az $\mathrm{OM}$ a $\mathrm{P}_{\mathrm{i}}$-disszociáció ütemének fokozásán kívül mást is tesz az aktin-miozin ciklussal (46-48). In vitro motilitási vizsgálatokban is megerősítették, hogy OM hatására csökken az aktin filamentumok miozin-függő elmozdulásának sebessége $(38,46)$. Az in vitro kinetikai és motilitási adatok jól korreláltak az in vivo preklinikai és klinikai vizsgálatok eredményeivel is. Egészségesekben és szívelégtelen betegek OM-mel történő kezelése után végzett echokardiográfiai vizsgálatokban a szisztolés ejekciós idő és az ejekciós frakció fokozódását, illetve szöveti Doppler révén az összehúzódás sebességének csökkenését mutatták ki $(33,34)$. OM hatására tehát erősebb, tartósabb és lassabb szívizom-összehúzódások alakulnak ki. A $P_{i}$ disszociációja támogatása révén az aktin-miozin kereszthidak a gyengén rögzült konformációból erősen-kötött, erőgeneráló konformációba mennek át. $A P_{i}$ disszociációjának gyorsítása önmagában azonban nem magyarázza a keresztkötési ciklus sebességének csökkenését, amelynek közvetlen következményének tekinthető a szívizomsejtek kontrakciós idejének növekedése. A szer hatásmechanizmusának pontosabb 
megértéséhez a kulcsot a $P_{i}$ disszociációjának fokozódása és a kontrakció kinetikájának lassítása közötti látszólagos ellentmondás feloldása jelentheti. Az OM molekuláris hatásmechanizmus megértése szempontjából ezért fontos lehet az a felismerés is, miszerint az OM gátolja (a $P_{i}-n$ kívüli másik ATP-degradációs végtermék,) az ADP leválását a miozin-fejekről, és ezáltal csökken az aktin-miozin komplex disszociációjának sebessége. Mindezeknek köszönhetően az aktin-miozin ciklus az erősen kötött konformációjú aktin-miozin komplex képződése és tartós fennmaradása irányába tolódik el. Mindez a vékony filamentumokon olyan kooperatív folyamatokat kezdeményez, amely növeli a miofilamentumok $\mathrm{Ca}^{2+}$-érzékenységét. A fokozódó kooperativitás együtt járhat az aktin filamentumokat gátló fehérjekomplexek inaktivációjával, amely időben elnyúlt aktin-miozin kölcsönhatást eredményez. Öszszességében, OM hatására hosszabb ideig tartó aktív kontrakció jön létre, a relaxáció lassulásával (27, 49). Végeredményben tehát az OM-et a szó szigorú értelmében nem tekinthetjük egyszerüen miozin-aktivátornak, sokkal inkább az aktin-miozin rendszer alloszterikus modulátorának, amely a myocardium konktraktilis funkcióját a $\mathrm{Ca}^{2+}$-érzékenység fokozásán keresztül támogatja (46).

\section{Következtetések}

Az OM olyan $\mathrm{Ca}^{2+}$-érzékenyítő szer, amelynek hatása az aktin-miozin interakció modulálásával a pozitív inotrópia „downstream” mechanizmusán keresztül érvényesül. Az OM mechanikai hatásai, illetve az aktin-miozin ciklus aktivációs-relaxációs kinetikájának lassítása erősebb, tartósabb és lassabb kontrakciókat hoz létre. OM alkalmazásakor számolni kell a diasztolés diszfunkció veszélyének fokozódásával a diasztolés idő rövidülése, a relaxáció lassulása és a diasztolés $\left[\mathrm{Ca}^{2+}\right]-n$ létrejövő $\mathrm{Ca}^{2+}$-érzékenyítés következtében. $\mathrm{Az}$ OM a szívizomsejtekben leírtakhoz hasonló kinetikai és mechanikai hatásokat fejt ki lassú vázizomrostokban az identikus $\beta-\mathrm{MHC}$ tartalom miatt. Az ATOMIC-HF-tanulmányban az OM inotróp hatásait vizsgálták akut szívelégtelenségben szenvedő betegek körében és az elsődleges végpontként a nehézlégzés javulását tekintették. Az OM nagyobb koncentrációkban egyes betegekben csökkentette a fulladásos panaszokat, amelynek hátterében a szer előnyös hemodinamikai hatása, de saját eredményeink szerint akár a légzőizmok farmakológiai támogatása is állhatott.

\section{Köszönetnyilvánítás}

ApublikációelkészítésétaGINOP-2.3.2-15-2016-00048 számú és az OTKA/NKFIH K 109083 számú projektek támogatták. A projekt az Európai Unió támogatásával, az Európai Regionális Fejlesztési Alap társfinanszírozásával valósult meg.
Irodalom

1. Endoh M. Cardiac Ca $\mathrm{Ca}^{2+}$ signaling and $\mathrm{Ca}^{2+}$ sensitizers. Circ J 2008; 72 1915-1925. Doi 10.1253/circj.CJ-08-0838

2. Tacon CL, McCaffrey J, Delaney A. Dobutamine for patients with severe heart failure: a systematic review and meta-analysis of randomised controlled trials. Intensive Care Med 2012; 38: 359-367. Doi 10.1007/s00134-011. 2435-6

3. O'Connor CM, Gattis WA, Uretsky BF, et al. Continuous intravenous dobutamine is associated with an increased risk of death in patients with advanced heart failure: insights from the Flolan International Randomized Survival Trial (FIRST). Am Heart J 1999; 138: 78-86. Doi 10.1016/S0002-8703(99)70250-4 4. Nagy L, Pollesello P, Papp Z. Inotropes and inodilators for acute heart failure: sarcomere active drugs in focus. J Cardiovasc Pharmacol 2014; 64: 199-208. Doi 10.1097/FJC.0000000000000113

5. Burchfield JS, Xie M,Hill JA. Pathological ventricular remodeling: mechanisms: part 1 of 2. Circulation 2013; 128: 388-400. Doi 10.1161/CIRCULATIONAHA.113.001878.

6. Dzau VJ. Autocrine and paracrine mechanisms in the pathophysiology of heart failure. Am J Cardiol 1992; 70: 4C-11C. Doi 10.1016/00029149(92)91352-5

7. Francis GS, Pierpont GL. Pathophysiology of congestive heart failure secondary to congestive and ischemic cardiomyopathy. Cardiovasc Clin 1988; 19: $57-74$.

8. Houser SR, Margulies KB. Is depressed myocyte contractility centraly ly involved in heart failure? Circ Res 2003; 92: 350-358. Doi 10.1161/01. RES.0000060027.40275.A6

9. Pieske B, Maier LS, Bers DM, et al. $\mathrm{Ca}^{2+}$ handling and sarcoplasmic reticulum $\mathrm{Ca}^{2+}$ content in isolated failing and nonfailing human myocardium. Circ Res 1999; 85: 38-46. Doi 10.1161/01.RES.85.1.38

10. Beuckelmann DJ, Nabauer M, Erdmann E. Intracellular calcium handling in isolated ventricular myocytes from patients with terminal heart failure. Circulation 1992; 85: 1046-1055. Doi 10.1161/01.CIR.85.3.1046

11. Del Monte F, Butler K, Boecker W, et al. Novel technique of aortic banding followed by gene transfer during hypertrophy and heart failure. Physiol Genomics 2002; 9: 49-56. Doi 10.1152/physiolgenomics.00035.2001

12. Lyon AR, Bannister ML, Collins T, et al. SERCA2a gene transfer decreases sarcoplasmic reticulum calcium leak and reduces ventricular arrhythmias in a model of chronic heart failure. Circ Arrhythm Electrophysiol 2011; 4 362-372. Doi 10.1161/CIRCEP.110.961615

13. del Monte F, Harding SE, Dec GW, et al. Targeting phospholamban by gene transfer in human heart failure. Circulation 2002; 105: 904-907. Doi 10.1161/hc0802.105564

14. Hasenfuss G, Schillinger W, Lehnart SE, et al. Relationship between $\mathrm{Na}^{+}-\mathrm{Ca}^{2+}$-exchanger protein levels and diastolic function of failing human myocardium. Circulation 1999; 99: 641-648. Doi 10.1161/01.CIR.99.5.641 15. Canton M, Menazza S, Sheeran FL, et al. Oxidation of myofibrillar proteins in human heart failure. J Am Coll Cardiol 2011; 57: 300-309. Doi 10.1016/j. acc.2010.06.058

16. Belin RJ, Sumandea MP, Allen EJ, et al. Augmented protein kinase C-alpha-induced myofilament protein phosphorylation contributes to myofilament dysfunction in experimental congestive heart failure. Circ Res 2007; 101: 195-204. Doi 10.1161/CIRCRESAHA.107.148289

17. Gomes AV, Potter JD, Szczesna-Cordary D. The role of troponins in muscle contraction. IUBMB Life 2002; 54: 323-333. Doi 10.1080/15216540216037 18. Katz AM, Lorell BH. Regulation of cardiac contraction and relaxation. Circulation 2000; 102: IV69-74. Doi 10.1161/01.CIR.102.suppl_4.IV-69

19. Kass DA, Solaro RJ. Mechanisms and use of calcium-sensitizing agents in the failing heart. Circulation 2006; 113: 305-315. Doi 10.1161/CIRCULATIONAHA.105.542407

20. McMurray JJ, Adamopoulos S, Anker SD, et al. ESC Guidelines for the diagnosis and treatment of acute and chronic heart failure 2012: The Task Force for the Diagnosis and Treatment of Acute and Chronic Heart Failure 2012 of the European Society of Cardiology. Developed in collaboration with the Heart Failure Association (HFA) of the ESC. Eur Heart J 2012; 33: 1787-1847. Doi 10.1093/eurheartj/ehs104

21. Ponikowski P, Voors AA, Anker SD, et al. 2016 ESC Guidelines for the diagnosis and treatment of acute and chronic heart failure: The Task Force for the diagnosis and treatment of acute and chronic heart failure of the European Society of Cardiology (ESC). Developed with the special contribution of the Heart Failure Association (HFA) of the ESC. Eur J Heart Fail 2016. Doi 10.1093/eurheartj/ehw128

22. Pang PS, Komajda M, Gheorghiade M. The current and future manage- 
ment of acute heart failure syndromes. Eur Heart J 2010; 31: 784-793. Doi $10.1093 /$ eurheartj/ehq049

23. Webster KA, Bodi I, McNamara JP, et al. Negative lusitropy and abnormal calcium handling in hypoxic cardiac myocytes exposed to the calcium-sensitize EMD 53998. J Mol Cell Cardiol 1993; 25: 747-751. Doi 10.1006/jmcc.1993.1087 24. Morgan BP, Muci A, Lu PP, et al. Discovery of omecamtiv mecarbil the first, selective, small molecule activator of cardiac Myosin. ACS Med Chem Lett 2010; 1: 472-477. Doi 10.1021/ml100138d

25. Malik FI, Hartman JJ, Elias KA, et al. Cardiac myosin activation: a potential therapeutic approach for systolic heart failure. Science 2011; 331: 14391443. Doi $10.1126 /$ science.1200113

26. Malik FI, Morgan BP. Cardiac myosin activation part 1: from concept to clinic. J Mol Cell Cardiol 2011; 51: 454-461. Doi 10.1016/j.yjmcc.2011.05.006 27. Nagy L, Kovacs A, Bodi B, et al. The novel cardiac myosin activator omecamtiv mecarbil increases the calcium sensitivity of force production in isolated cardiomyocytes and skeletal muscle fibres of the rat. $\mathrm{Br} \mathrm{J}$ Pharmacol 2015; 172: 4506-4518. Doi 10.1111/bph.13235

28. Shen YT, Malik FI, Zhao X, et al. Improvement of cardiac function by a cardiac Myosin activator in conscious dogs with systolic heart failure. Circ Heart Fail 2010; 3: 522-527. Doi 10.1161/CIRCHEARTFAILURE.109.930321 29. Bakkehaug JP, Kildal AB, Engstad ET, et al. Myosin Activator Omecamtiv Mecarbil Increases Myocardial Oxygen Consumption and Impairs Cardiac Efficiency Mediated by Resting Myosin ATPase Activity. Circ Heart Fail 2015 8: 766-775. Doi 10.1161/CIRCHEARTFAILURE.114.002152

30. Ottenheijm CA, Jenniskens GJ, Geraedts MC, et al. Diaphragm dysfunction in chronic obstructive pulmonary disease: a role for heparan sulphate? Eur Respir J 2007; 30: 80-89. Doi 10.1183/09031936.00125100

31. Powers SK, Kavazis AN, Levine S. Prolonged mechanical ventilation alters diaphragmatic structure and function. Crit Care Med 2009; 37: S347353. Doi 10.1097/CCM.0b013e3181b6e760

32. Ochala J, Radell PJ, Eriksson LI, et al. EMD 57033 partially reverses ventilator-induced diaphragm muscle fibre calcium desensitisation. Pflugers Arch 2010; 459: 475-483. Doi 10.1007/s00424-009-0744-1

33. Teerlink JR, Clarke CP, Saikali KG, et al. Dose-dependent augmentation of cardiac systolic function with the selective cardiac myosin activator omecamtiv mecarbil: a first-in-man study. Lancet 2011; 378: 667-675. Do 10.1016/S0140-6736(11)61219-1

34. Cleland JG, Teerlink JR, Senior R, et al. The effects of the cardiac myosin activator, omecamtiv mecarbil, on cardiac function in systolic heart failure: a double-blind, placebo-controlled, crossover, dose-ranging phase 2 trial. Lancet 2011; 378: 676-683. Doi 10.1016/S0140-6736(11)61126-4

35. Palaparthy R, Banfield C, Alvarez P, et al. Relative bioavailability, food effect, and safety of the single-dose pharmacokinetics of omecamtiv mecarbil following administration of different modified-release formulations in healthy subjects. Int J Clin Pharmacol Ther 2016; 54: 217-227. Doi 10.5414/CP202458 36. Teerlink JR, Felker GM, McMurray JJ, et al. Acute Treatment With Omecam- tiv Mecarbil to Increase Contractility in Acute Heart Failure: The ATOMIC-AHF Study. J Am Coll Cardiol 2016; 67: 1444-1455. Doi 10.1016/j.jacc.2016.01.031 37. Teerlink JR, Felker GM, McMurray JJ, et al. Chronic Oral Study of Myosin Activation to Increase Contractility in Heart Failure (COSMIC-HF): a phase 2, pharmacokinetic, randomised, placebo-controlled trial. Lancet 2016; 388 : 2895-2903. Doi 10.1016/S0140-6736(16)32049-9

38. Wang Y, Ajtai K, Burghardt TP Analytical comparison of natural and pharmaceutical ventricular myosin activators. Biochemistry 2014; 53: 5298-5306.

\section{Doi $10.1021 /$ bi500730}

39. Szentandrassy N, Horvath B, Vaczi K, et al. Dose-dependent electrophysiological effects of the myosin activator omecamtiv mecarbil in canine ventricular cardiomyocytes. J Physiol Pharmacol 2016; 67: 483-489.

40. Nanasi P, Jr., Vaczi K, Papp Z. The myosin activator omecamtiv mecarbil a promising new inotropic agent. Can J Physiol Pharmacol 2016; 94: 10331039. Doi 10.1139/cjpp-2015-0573

41. Palmer S, Di Bello S, Herzig JW. The effects of EMD 57033 on rigor tension in porcine skinned cardiac trabecula. Eur J Pharmacol 1995; 294 83-90. Doi 10.1016/0014-2999(95)00509-9

42. Ishisu R, Abe Y, Onishi K, et al. Differential effects of EMD-53998 on calcium-pressure relationship in normal and ischemic guinea pig heart. Am $J$ Physiol 1996; 271: H311-319.

43. Papp Z, Van Der Velden J, Borbely A, et al. Effects of Ca2+ -sensitizers in permeabilized cardiac myocytes from donor and end-stage failing human hearts. J Muscle Res Cell Motil 2004; 25: 219-224. Doi 10.1023/B:JU-

\section{RE.0000038365.74532.75}

44. van der Velden J, Papp Z, Zaremba R, et al. Increased $\mathrm{Ca}^{2+}$-sensitivity of the contractile apparatus in end-stage human heart failure results from altered phosphorylation of contractile proteins. Cardiovasc Res 2003; 57: 37-47. Doi 10.1016/S0008-6363(02)00606-5

45. Wilson K, Guggilam A, West TA, et al. Effects of a myofilament calcium sensitizer on left ventricular systolic and diastolic function in rats with volume overload heart failure. Am J Physiol Heart Circ Physiol 2014; 307: H16051617. Doi 10.1152/ajpheart.00423.2014

46. Liu Y, White HD, Belknap B, et al. Omecamtiv Mecarbil modulates the kinetic and motile properties of porcine beta-cardiac myosin. Biochemistry 2015; 54: 1963-1975. Doi 10.1021/bi5015166

47. Rohde JA, Thomas DD, Muretta JM. Heart failure drug changes the mechano-enzymology of the cardiac myosin powerstroke. Proc Natl Acad Sci USA 2017. Doi 10.1073/pnas.1611698114

48. Swenson AM, Tang W, Blair CA, et al. Omecamtiv Mecarbil Enhances the Duty Ratio of Human Beta Cardiac Myosin Resulting in Increased Calcium Sensitivity and Slowed Force Development in Cardiac Muscle. J Biol Chem 2017. Doi 10.1074/jbc.M116.74878

49. Poggesi C, Tesi C, Stehle R. Sarcomeric determinants of striated muscle relaxation kinetics. Pflugers Arch 2005; 449: 505-517. Doi 10.1007/s00424. 004-1363-5

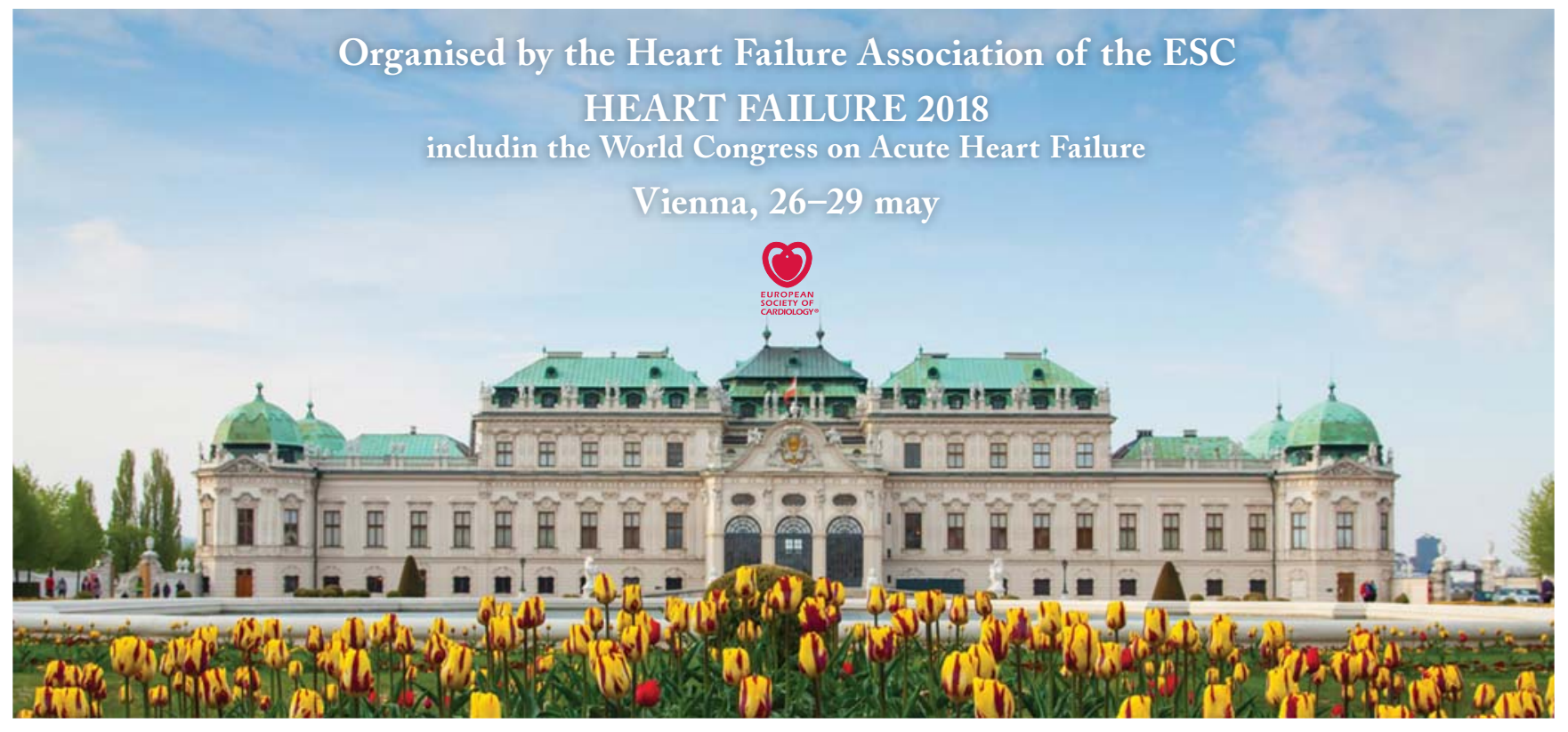

